\title{
Guidelines for bisphosphonate-associated osteonecrosis of the jaw
}

\author{
Khan AA, Sándor GK, Dore E, et al. \\ Canadian consensus practice guidelines for bisphosphonate associ- \\ ated osteonecrosis of the jaw. J Rheumatol 2008; 35:1391-1397
}

Scope and purpose This guideline aimed to provide recommendations for the diagnosis of bisphosphonate-associated osteonecrosis of the jaw in both the oncology and osteoporosis patient populations, for dental and medical practitioners including dentists, oral surgeons, oral pathologists, general practitioners and internal medicine specialists. The recommendations are intended to address both prevention and treatment strategies.

Methods A consensus-based guideline was developed by a multidisciplinary task force including representatives from national and international societies representing the disciplines of oral surgery, dentistry, oral pathology, oral medicine, endocrinology, rheumatology and oncology. The task force reviewed data collected for a systematic review and prepared discus-

Table 1. Summary of main recommendations of the Canadian consensus practice guidelines for bisphosphonate-associated ONJ

\begin{tabular}{l|l}
\hline Patient group & $\begin{array}{l}\text { Recommended action by } \\
\text { dental practitioner }\end{array}$ \\
\hline $\begin{array}{l}\text { All patients taking } \\
\text { bisphosphonates }\end{array}$ & $\begin{array}{l}\text { Stopping smoking, limiting alcohol intake, } \\
\text { and maintaining good oral hygiene should be } \\
\text { emphasised }\end{array}$ \\
\hline $\begin{array}{l}\text { All oncology } \\
\text { patients taking } \\
\text { bisphosphonates }\end{array}$ & $\begin{array}{l}\text { A thorough dental examination including } \\
\text { radiographs should be completed prior to the } \\
\text { initiation of intravenous bisphosphonate therapy }\end{array}$ \\
\cline { 2 - 2 } & $\begin{array}{l}\text { Any invasive dental procedure ideally to be } \\
\text { completed prior to initiation of high-dose } \\
\text { bisphosphonate therapy }\end{array}$ \\
\cline { 2 - 2 } & $\begin{array}{l}\text { Nonurgent procedures preferably to be } \\
\text { delayed for 3-6 months following interruption } \\
\text { of bisphosphonate therapy }\end{array}$ \\
\hline \multirow{2}{*}{$\begin{array}{l}\text { Osteoporosis patients } \\
\text { taking oral/ intravenous } \\
\text { bisphosphonates }\end{array}$} & $\begin{array}{l}\text { Dental examination not required prior to } \\
\text { initiating therapy if there is appropriate dental } \\
\text { care and good oral hygiene }\end{array}$ \\
\hline \multirow{2}{*}{$\begin{array}{l}\text { Individuals with } \\
\text { established ONJ }\end{array}$} & $\begin{array}{l}\text { Best managed with supportive care including pain } \\
\text { control, treatment of secondary infection, removal } \\
\text { of necrotic debris, and mobile sequestrate }\end{array}$ \\
\cline { 2 - 2 } & Aggressive debridement is contraindicated. \\
\hline
\end{tabular}

ONJ, Osteonecrosis of the jaw.

Address for correspondence: A.A. Khan, Professor of Clinical Medicine, Divisions of Endocrinology and Geriatrics, McMaster University, Hamilton, Ontario, Canada sion papers. The systematic review included searches of Medline, Embase and a manual search of the bibliographies of published articles. A draft guideline was circulated to all members of the task force as well as external experts, and their feedback incorporated into the final document.

Recommendations The main recommendations are summarised in Table 1. The task force also recommended that a registry be maintained for all identified cases.

\section{Commentary}

Bisphosphonates are mainly used for the treatment of osteoporosis, but they are also used in the treatment of cancer. Cancer patients often take them in higher doses than are used for noncancer treatments, and often do so intravenously. Bisphosphonate-associated osteonecrosis is a rare clinical entity that is poorly understood: estimates of its incidence in patients on oral bisphosphonate therapy range between 1:10 000 and $1: 100000$, rising to $1: 10-1: 100$ in cancer patients taking high-dose intravenous bisphosphonates. ${ }^{1}$ The number of cases is increasing, however: this may be caused by improving recognition of the condition, the use of more potent bisphosphonates, or the increased use of this group of drugs. Osteonecrosis is the jaw (ONJ) is diagnosed clinically as the presence of exposed bone in the maxillofacial region for more than 8 weeks in the absence of radiotherapy to the jaw. ${ }^{2}$

As well as more cases, the number of publications related to ONJ has also gone up. A simple search of Medline (search terms: bisphosphonates and osteonecrosis) identifies over 750 papers with about 140 reviews. As found in the review upon which the guideline is based, the amount of high-quality information on this topic is currently limited, however.

The recommendations from the Canadian task group are in line with those from other groups. ${ }^{3,4}$ Reading other guidance documents reveals two main areas of disagreement: the use of prophylactic antibiotics prior to minor surgical procedures when people are taking bisphosphonates, and the discontinuation of bisphosphonate treatment (should the patient's clinical situation allow) for the treatment of ONJ.

\section{Table 2. Stages of ONJ}

\begin{tabular}{l|l}
\hline Stage & Presentation \\
\hline Stage 1 & $\begin{array}{l}\text { Exposed/ necrotic bone in people who are asymptomatic } \\
\text { and have no evidence of infection }\end{array}$ \\
\hline Stage 2 & $\begin{array}{l}\text { Exposed/ necrotic bone in people who experience pain and } \\
\text { have clinical evidence of infection, such as erythema in the } \\
\text { region of the exposed bone, with/ without purulent drainage }\end{array}$ \\
\hline Stage 3 & $\begin{array}{l}\text { Exposed/ necrotic bone in people who have pain, infection } \\
\text { and one or more of the following: pathological fracture, } \\
\text { extra-oral fistula, or osteolysis extending to the inferior border }\end{array}$ \\
\hline
\end{tabular}

ONJ, Osteonecrosis of the jaw. 
Regarding prophylactic antibiotics, the American Dental Association (ADA) expert panel ${ }^{3}$ found no evidence that their use was effective in preventing ONJ and recommended that, "Prophylactic antibiotics after a surgical procedure should be based on the risk of an infection and NOT because the patient is taking a bisphosphonate." The British Dental Association (BDA) factfile on bisphosphonates ${ }^{4}$ takes a similar position.

The interruption of bisphosphonate therapy for 3-6 months is recommended in this Canadian guideline for nonemergency invasive dental treatment, but the half-life of bisphosphonates in the skeleton is high and there is only anecdotal evidence to support this approach. The guideline does highlight that cessation of bisphosphonate therapy for several months does not seem to have a detrimental effect on osteoporosis management. ${ }^{5}$ In view of the lack of robust evidence, the BDA factfile's recommendation, to assess the clinical situation and discuss it with the patient's physician or oncologist before stopping the bisphosphonates, seems the more realistic approach.

The guidance identifies three stages of ONJ (see Table 2) and a range of treatments for each stage. No prospective studies assessing the effectiveness of these treatments were identified, so it is recommended that conservative approaches are the most effective. This remains a relatively rare condition despite the increasing numbers, but is one of which dentists should be aware. These broad consensus guidelines provide useful advice to practitioners. The ADA and BDA recommendations (Table 3 and see www.bda.org) provide additional specific advice for dentists.
The available evidence-base for ONJ is limited at present as this is a relatively new clinical entity, with the first cases being reported in 2003. ${ }^{6}$ There are knowledge gaps, therefore, as highlighted in this guideline. These include a lack of understanding of the pathogenesis and true incidence of $\mathrm{ONJ}$, and the prospective data needed to stratify risk factors and develop prevention and management recommendations. These well-developed multidisciplinary guidelines are a useful step to raising awareness of the profession's role in prevention and management of this condition.

\section{Derek Richards}

\section{Centre for Evidence-based Dentistry, Oxford, UK}

1. Arrain $Y$, Masud T. Recent recommendations on bisphophonate associated osteonecrosis of the jaw. Dental Update 2008; 35:238-242

2. Barker K, Rogers S. Bisphosphate associated osteonecrosis of the jaws: a guide for the general practitioner. Dental Update 2006; 33:270-275.

3. American Dental Association. Dental Management of Patients Receiving Oral Bisphosphonate Therapy. Expert Panel Recommendations Report of the Council on Scientific Affairs. Chicago: American Dental Association; 2008.

4. British Dental Association_Bisphosphonates. Fact File. London: British Dental Association; 2008.

5. Black DM, Schwartz AV, Ensrud KE, et al. Effects of continuing or stopping alendronate after 5 years of treatment: the Fracture Intervention Trial Long-term Extension (FLEX): a randomized trial. J Am Med Assoc 2006; 296:2927-2938.

6. Marx RE. Pamidronate (Aredia) and zoledronate (Zometa) induced avascular necrosis of the jaws: a growing epidemic. J Oral Maxillofac Surg 2003; 61:1115-1117.

Evidence-Based Dentistry (2008) 9, 101-102. doi:10.1038/sj.ebd.6400608

\begin{tabular}{|c|c|c|}
\hline Dental procedure & $\begin{array}{l}\text { People with osteoporosis or other nonmalignant disease } \\
\text { who have taken bisphosphonates }>3 \text { years }\end{array}$ & $\begin{array}{l}\text { Patients with malignancy, starting or already receiving } \\
\text { bisphosphonates }\end{array}$ \\
\hline Dental regime & Regular dental visits, oral health maintenance & $\begin{array}{l}\text { Regular dental visits, oral health maintenance: 6-12-monthly dental } \\
\text { exams or as clinical/ dental status demands }\end{array}$ \\
\hline $\begin{array}{l}\text { Dental } \\
\text { exam pre- } \\
\text { bisphosphonate } \\
\text { therapy }\end{array}$ & $\begin{array}{l}\text { No. Risk of ONJ is low so no additional dental examination is } \\
\text { needed nor change to routine dental care. } \\
\text { However where there has been a lack of previous, routine, } \\
\text { dental care, a dental checkup should be undertaken, with any } \\
\text { dental treatment, especially acute treatment, being addressed } \\
\text { before patients begin a bisphosphonates prescription }\end{array}$ & $\begin{array}{l}\text { Yes. Before starting intravenous bisphosphonates for bone metastasis. } \\
\text { Invasive dental procedures, if needed, should be carried out and healing } \\
\text { completed before starting bisphosphonates if the patient's clinical } \\
\text { treatment allows. Liaise with physicians/ oncologists. If not possible, need } \\
\text { careful followup of surgical sites. }\end{array}$ \\
\hline Extractions & $\begin{array}{l}\text { Extractions are not contra-indicated as risk of ON J } \\
\text { low. Root treatment is preferable. If coronally } \\
\text { unrestorable amputate to root level after root treatment } \\
\text { and seal. If tooth extracted, best to carry out atraumatic } \\
\text { extractions and careful socket followup: refer if chronic } \\
\text { exposed bone }\end{array}$ & $\begin{array}{l}\text { Avoid extractions wherever possible as increased risk of ONJ. Root } \\
\text { treatment preferable and if coronally unrestorable can amputate to } \\
\text { root level after root treatment and seal. } \\
\text { For periodontally affected teeth, only extract if excessive mobility and } \\
\text { aspiration risk. } \\
\text { Symptomatic teeth in an area of bone that is already exposed and } \\
\text { necrotic can be extracted as established necrotic process will not be } \\
\text { exacerbated by this. If unsavable, eg, vertical root fracture and extraction } \\
\text { needed, very careful followup of surgical site is important }\end{array}$ \\
\hline $\begin{array}{l}\text { Periodontal } \\
\text { disease }\end{array}$ & $\begin{array}{l}\text { Periodontal surgery is appropriate if it reduces or eliminates } \\
\text { bone disease. Can carry out modest bone contouring }\end{array}$ & $\begin{array}{l}\text { Periodontal surgery is not recommended. Nonsurgical periodontal } \\
\text { treatment only }\end{array}$ \\
\hline Dentures & Need good-fitting dentures & Good-fitting dentures possibly with soft lining to prevent trauma \\
\hline Endodontics & $\begin{array}{l}\text { Avoid apical surgery. Conventional orthograde } \\
\text { endodontics recommended rather than extraction where } \\
\text { possible. Good coronal seal maintenance important }\end{array}$ & $\begin{array}{l}\text { Avoid apical surgery. Conventional orthograde endodontics } \\
\text { recommended rather than extraction where possible. Good coronal } \\
\text { seal maintenance important }\end{array}$ \\
\hline Implants & $\begin{array}{l}\text { Currently not contra-indicated if taking bisphosphonates } \\
\text { but prudent to gain informed consent which should be } \\
\text { documented (risk assessment) }\end{array}$ & $\begin{array}{l}\text { Not recommended and avoid elective surgery such as } \\
\text { tori removal }\end{array}$ \\
\hline
\end{tabular}

ONJ, Osteonecrosis of the jaw. 